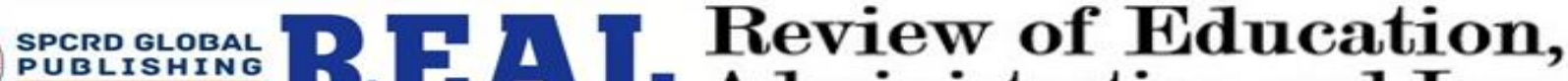 Administration and Law \\ Journal homepage: http://real.spcrd.org ISSN (Print): 2708-1788

\section{Extremism \& Terrorism: A Political Issue or An Economic One?}

\author{
${ }^{\text {a }}$ Hina Ali, ${ }^{\text {b Sumaira Khalid, }}{ }^{\mathrm{c}}$ Iqra Ashraf, ${ }^{\mathrm{d}}$ Naheed Anwar \\ ${ }^{a}$ Assistant Professor, Department of Economics, The Women University, Multan \\ Email: hinaali@wum.edu.pk \\ ${ }^{\mathrm{b}}$ Lecturer, Department of Mass Communication, The Women University, Multan \\ Email: sumera.6379@wum.edu.pk \\ ${ }^{c}$ Lecturer, Department of History and Pakistan Studies, The Women University, Multan \\ Email: iqrachaudhry3o@gmail.com \\ ${ }^{\mathrm{d}}$ PhD Scholar, Department of History and Pakistan Studies, The Women University, Multan \\ Email: qazinaheed75@gmail.com
}

\begin{tabular}{l}
\hline ARTICLE DETAILS \\
\hline History: \\
Accepted 16 March 2021 \\
Available Online March 2021 \\
\\
Keywords: \\
Terrorism, Economic Stability, \\
Political Instability, Poverty, \\
Foreign Involvement, Regional \\
Disparities
\end{tabular}

JEL Classification:

K14, P26, P16, Z32, R11, I32

DOI: $10.47067 /$ real.v4i1.124

\begin{abstract}
Extremism and terrorism have become a serious threat to Pakistan's security and well-being. Pakistan is situated in an uncomfortable and unfriendly neighborhood and faces an existential challenge from domestic forces of sectional and ethnic militancy and terrorism. These problems started after the 9/11 attacks. The extremists have not only affected the life in tribal areas but have also invaded the well-developed urban cities of Pakistan as well. The lusts for power, religious differences, regional disparities, political instability, illiteracy, foreign involvements, Afghan Jihad of 1975, low socioeconomic indicators, and non-democratic values are a few of the many reasons that have added fuel to the fire of militancy, terrorism, and extremism. More than 75 thousand people in Pakistan have either been killed by terrorist groups or have become a victim of religious militants and extremists. To address these problems Pakistan took a few measures such as the launching of Zarb-e-Azab, amendments to the Unlawful Activities (Prevention) Act, 1967, the establishment of NATGRID, creating awareness about religion, revising Madrassa reforms, etc. All these efforts have solved the problem but only to some extent. There is a dire need for more strict measures not only by the Government but also by the civilians. Together, they need to keep working against these evils because they have eaten up the credibility, economic stability, reputation, well-being and peace of the country.
\end{abstract}

(C) 2021 The authors. Published by SPCRD Global Publishing. This is an open access article under the Creative Commons AttributionNonCommercial 4.0

Corresponding author's email address: hinaali@wum.edu.pk

\section{Introduction}

We cannot turn a 'Blind Eye' to the rapidly swelling religious extremism and bigotry in our 
society. Sectarian violence and religious extremism is unpredictable menace. History is sated with incidents of such types in various nations. The bigots and the evil-minded self-centered natured people are behind this hideous act. Unfortunate is the fact that usually the Muslim countries are being continuously blamed for encouraging these evil acts and take 'jihad' in terms of terror.

Terrorism overall means the use of intentionally indiscriminate violence (terror or fear) for achieving a religious, political, or ideological purpose. Terrorism not only means violence against the laws of the country but it also includes all those activities which aim at disturbing the peaceful setup of a country just for achieving an immoral goal. Terrorism in Pakistan has turned out to be a key and intimidating problem. The number of people who die annually from terrorist attacks has increased from 164 in 2003 to 3318 in 2009, with a total of 35,000 Pakistanis massacred between September 11, 2001, and May 2011. Terrorism has cost $\$ 68$ billion to the government of Pakistan in recent years. After martial law was imposed in 1958, Pakistan's political situation changed dramatically. Political rivalry and intense disputes over business resulted in the proliferation of terrorist activities. The roots of terrorism in Pakistan can be traced back to the 1980s when Zia-ul-Haq implemented the Islamization policy. That policy resulted in conflicts arising between Afghanistan and the Soviet Union. Pakistan's intervention in the Soviet-Afghan war led to a great inflow of Mujahideen to the tribal areas of Baluchistan. The encounter brought several combatants from all over the world to South Asia in the name of jihad. The mujahideen fighters were made competent from the training given by Pakistan's military, American CIA and other western intelligence agencies, who carried out mutinous activities inside Afghanistan well after the war formally ended. Though the war ended the violent streak of the mujahideen never ended.

Terrorist activities flourished in Pakistan after 2007. A large number of people were killed in suicide attacks and targeted bombing. The reasons for these attacks included Sunni-Shia differences, the beginning of 'Kalashnikov' culture, easy availability of guns and explosives, presence of Islamist rebellious groups and formation of groups such as Taliban and Lashkar-e- Taiba.

Apart from terrorism, extremism is also one of the major problems in Pakistan. Extremism means, "the quality or state of being extreme" or "advocacy of extreme measures or views". Extremism is a term used politically and religiously for an ideology that does not match the common and mainstream behavior of society. It means acting out. In Pakistan, extremism has its peculiar characteristics. Extremism is the result of two factors:

1) Political Islam

2) Islamic revivalism

Over the last few decades, Islam has become a central point of reference for a wide range of political activities, arguments and opposition movements. The term "Political Islam" is used to classify the unmatched eruption of Islamic religion into the materialistic domain of politics and thus to discriminate these practices from the forms of personal piety, belief, and ritual orthodoxy incorporated in Western scholarship under the immaculate category "Islam." Political Islam refers to a self-created fact that religion has both a social and a political dimension, which demands the implementation of the scriptures in the political, economic, administrative, social, judicial and cultural domains of a Muslim state. And when government fails to do so, extremists emerge and create violence in the country by taking matters into their own hands. In 2005, approximately 4,000 people became a victim of extremism in Pakistan over religious and sectoral differences. 
On the other hand, Islamic revivalism generally means that the followers of the movement want to re-examine history and to recreate the splendid state and societal structures, which once absolutely distinguished Muslim civilizations from others. The extremists and terrorists have always been trying to attack the well-being of Pakistan; the instability of the political system of our country has made this task easier for them. The impositions of martial laws and dictatorships in the name of democracy have urged the civilians to get inclined towards the religious extremists in our country rather than following the rules of the so-called democratic state. The politicians of our country are more concerned with power rather than the development of the country. They just focus on the development of those areas where their voters reside. This leads to regional disparities. It creates hatred among the people, inciting the less privileged people to get engaged in illegal terrorist activities.

Moreover, the poor economic conditions of the country have created problems such as unemployment and poverty. Currently, the multi-dimensional poverty rate in Pakistan is $39 \%$. The poor people need to earn a living to feed their large families. When they fail to find jobs, family pressure urges them to get involved in terrorist activities. Apart from that, the involvement of America in the internal matters of our country has further aggravated the chaotic situation in the country.

The use of American hardware in the border areas and an anti-Pakistan emotion in the American media, which is regularly picked up by the local media and is discussed how America is using and molesting Pakistan at the same time, has created hatred in the hearts of Pakistanis hence urging the terrorists to create violence in the country in the name of promoting religious values. The uncertainty exercised by the Pakistani government vis-à-vis its military collaboration with the United States further worsens the situation. Today's impasse is to understand how political instability and the poor economic system got linked to extremism and terrorism. The instability in the system makes normal civilians violent. They become a victim of poverty and unemployment. At this point, angry civilians decide to take matters into their own hands and that is when terrorism and extremism disturb the peaceful setup of the country.

The purpose of this research is to find out that of all these factors which factor has the deepest impact on terrorist activities. Suggestions would then be provided to overcome these problems so that the menace of terrorism and extremism can be eradicated from the country.

\section{Review of Literature}

Terrorism can intensely influence the world, as shown across the board and by the persistent effects of the attacks in New York on 11th September 2001. Terrorism has flourished a lot since then. Some believe that terrorism and extremism have been promoted by poverty and poor economic conditions and some believe that unstable political conditions are the reason.

While some policymakers postulate a positive relationship between general support for terrorism and poverty, the prevailing experimental scholarship is underdeveloped (Blattman and Miguel 2010) and offers little support for this belief (Fair and Shepherd 2006; Von Hippel 2008; Shapiro and Fair 2010; Jo 2011).

James D. Fearon and David D. Laitin also found socio-economic factors to be significant causes of terrorism and extremism. n their experimental study of 127 civil wars between 1945 and 1999, Fearon and Laitin demonstrated that poverty is a positive forecaster of the violent national clash, along with general political instability, rough topography, and large population levels, because it is related to 
“financially and bureaucratically weak states".

Krueger and Laitin (2003) and Piazza (2004) have found no substantiation signifying that poverty might breed terrorism. Especially, the outcomes of Krueger and Laitin (2003) recommend that among countries with similar levels of legitimate rights, poor countries do not create more terrorism than rich countries. Contrariwise, among countries with analogous intensities of civil liberties, richer countries seem to be preferred targets for worldwide extremist attacks. Poverty, at the individual level, has long been believed to make people more vulnerable to militants' political demands, thereby expecting greater backing for such groups (Esposito and Voll 1996).

Individuals who feel helpless and isolated or unsatisfied by the performance of formal political institutions may be more likely to turn to extra-state organizations or to be influenced by groups who exploit individual political and economic defeats (Piazza 2007; Tessler and Robins 2007; Abadie 2006; Esposito and Voll 1996). Thus, it can be said that poor people support militants and extremists more vigorously than others. Moreover, poor people, who live in underdeveloped rural areas and are victims of regional disparities, are more supportive of terrorist activities than those living in developed urban areas.

It has been shown by Miguel, Satyanath, and Sergenti (2004) that, for a sample of African countries, destructive external shocks in economic growth increase the possibility of a public encounter. Because terrorism is a demonstration of the political clash, these results seem to indicate that poverty and hostile economic situations may play an important role in the amplification of terrorism.

Harold R. Kerbo (2005) pointed out the involvement of foreign powers and the role of foreign inspiration in affecting the frequency of domestic political fierceness in developing countries. Stephen M. Walt (2001) considers the threat to multinational security posed by "failed states" that are unable to govern their domestic grounds. Thus, it can be concluded that terrorism and extremism are majorly caused by poverty, regional disparities and poor economic indicators. And the poor economic indicators are a result of the unstable political situation in the country.

\section{Study Matrix:}

Terrorism and extremism are two major problems that have threatened the well-being of our society. From the study of the literature cited above it has been found out that these are the major factors that result in terrorism.

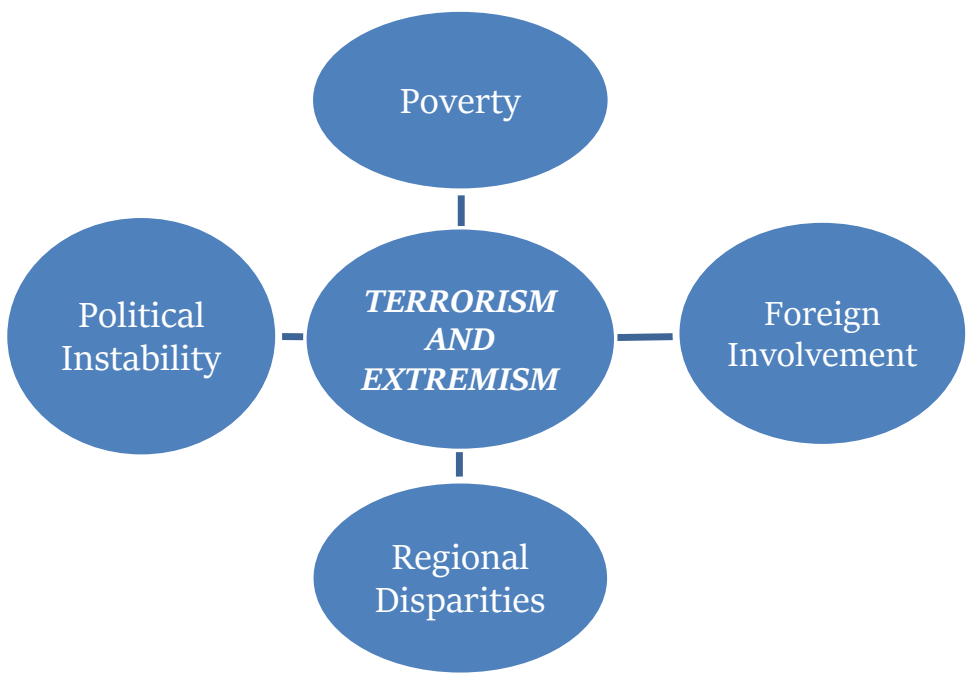




\section{Data Sources \& Methodology}

Data used basically for this purpose is secondary data. Data has been collected from various websites. Data from the year 2012 to 2015 has been used. The statistics regarding the terrorist activities in Pakistan in the said years have been taken from SATP (South Asia Terrorism Portal). The information regarding poverty and other economic factors has been collected from the Pakistan Bureau of Statistics. Comparative analysis has been done to show how the change in independent variables such as poverty, GDP growth and other economic variables affect the dependent variable terrorism and extremism.

\section{Findings and Discussion}

Terrorism and extremism have been threatening Pakistan's development for a very long time. The government has taken a lot of steps to fight this problem but hasn't succeeded fully. To come to the conclusion, which factor has the deepest impact on terrorism, we need to see the fluctuations in various factors about terrorism. The table below shows the summary of terrorist activities in Pakistan from the year 2012 to 2015:

Table 1: Summary of terrorist activities in Pakistan

\begin{tabular}{|c|c|c|}
\hline YEAR & CIVILIANS KILLED & TERRORISTS INVOLVED \\
\hline 2012 & 2738 & 676 \\
\hline 2013 & 3001 & 735 \\
\hline 2014 & 1781 & 533 \\
\hline 2015 & 940 & 339 \\
\hline
\end{tabular}

It shows that from the year 2012 to 2013 not only the number of people involved in terrorist activities increased in number but also the number of civilians killed rose to 3000. But after 2013, a noticeable change has been seen in the fall of the number of terrorists and also the number of people who became the victim of these terrorists. To find out what caused this dramatic cut down in terrorist activities, analysis of the independent variables has been done separately.

\subsection{Analysis of the variables}

The three independent variables whose impact on terrorism have been analyzed are:

1) Political Instability (Political factor)

2) Poverty (Economic factor)

3) Regional Disparities (Economic factor)

\subsubsection{Political Instability}

Political instability is the possibility of having protests, forms of viciousness, workers going on strike, or the possibility of a coup d'état. It is also measured in terms of whether the government may flop or not. In 2012 Pakistan's Peoples Party was the ruling party of the country. After the general elections held in 2013, PML (N) came into power. The election of Nawaz Sharif as the Prime Minister caused serious unrest in the country because the opposition wasn't ready to accept him as the representative of the country.

Analysts believed that at that time the political system was extremely unstable and that is why the terrorist activities increased in 2013 , but the international analysis websites think otherwise. "THE 
GLOBAL ECONOMY" forum has constructed an index to show the political stability of all the countries around the globe.

The index is a compound measure as it is based on several other indexes from manifold sources including the Economist Intelligence Unit, the World Economic Forum, and the Political Risk Services, among others. The principal indexes reflect the likelihood of an unsystematic transfer of government power, armed conflict, violent protests, social unrest, international pressures, terrorism, as well as ethnic, religious, or regional conflicts. According to the index formulated the score of Pakistan's POLITICAL STABILITY is as follow:

Table 1: Score of Pakistan's Political Stability

\begin{tabular}{|c|c|}
\hline YEAR & PAKISTAN SCORE OF POLITICAL STABILITY \\
\hline 2012 & -2.69 \\
\hline 2013 & -2.60 \\
\hline 2014 & -2.44 \\
\hline
\end{tabular}

Although the score is negative it has been improving from 2012 onward. The score rose from 2.69 to -2.60 from 2012 to 2013. This shows that although Pakistan is very low on the ladder of Political stability it is climbing up the ladder and not climbing down. This statistic clearly shows that Political instability is not the prominent cause of terrorism because terrorist activities increased in 2013 but at the same time the political conditions of our country also improved. Here it can be concluded that terrorism is not a political issue.

\subsubsection{Economic Factors}

Many economic factors result in terrorism. The four major economic factors are:

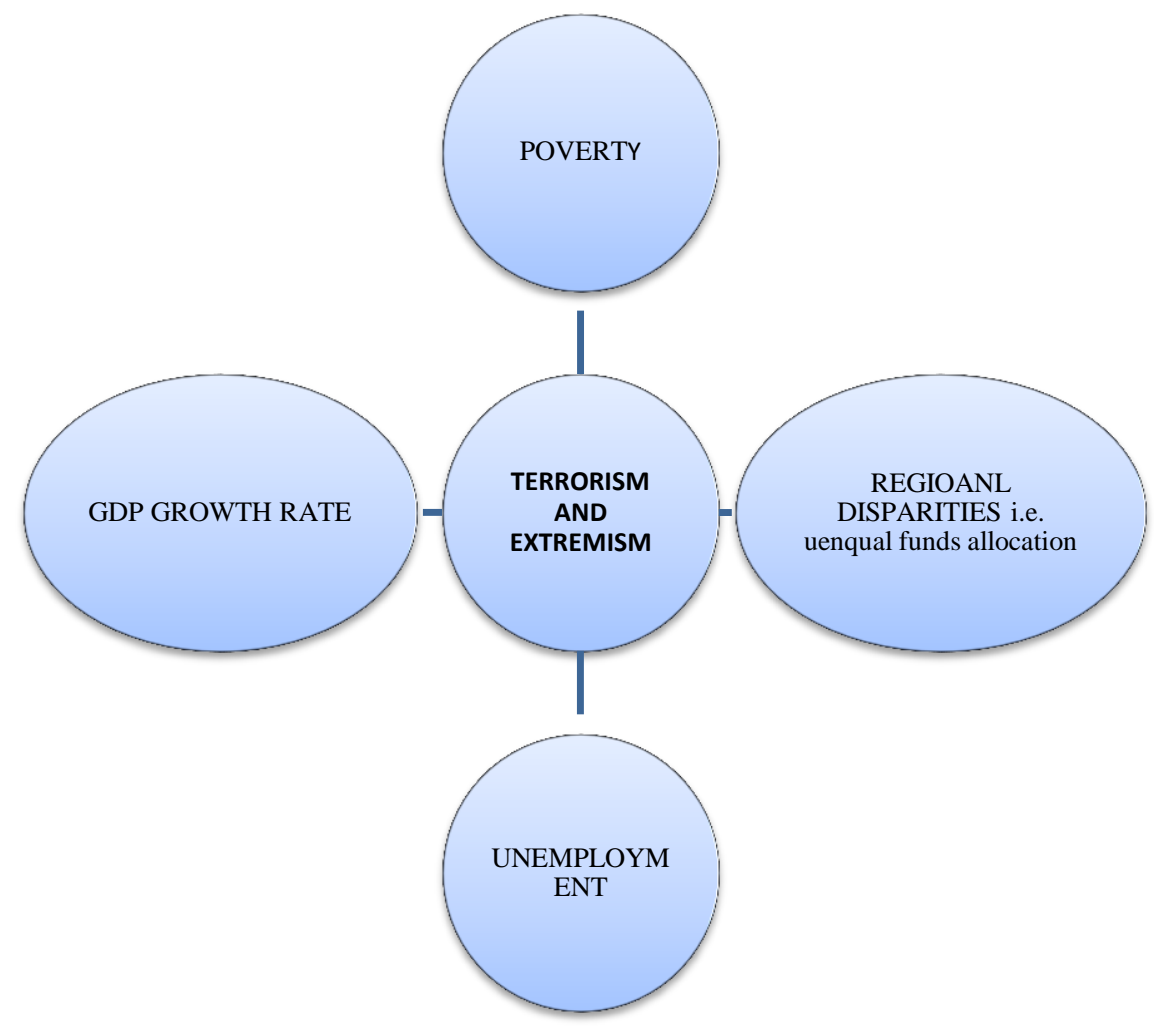


For our analysis we shall focus on these two:

1) Poverty

2) Regional Disparities

Poverty is general insufficiency or the state of one who lacks a certain number of quantifiable belongings or money. Pakistan has always been considered a third world country. Every international forum has declared Pakistan to be a poor country. We have been on a roller coaster ride of poverty in the years 2012 to 2015 .

Table 3: The data has been obtained from the World Bank (with the poverty line at \$1.25)

\begin{tabular}{|c|c|}
\hline YEAR & POVERTY RATIO \\
\hline 2012 & $12.7 \%$ \\
\hline 2013 & $29.5 \%$ \\
\hline 2014 & $21.04 \%$ \\
\hline 2015 & $13.1 \%$ \\
\hline
\end{tabular}

The table shows that the poverty ratio in Pakistan was 12.7\% in 2012 and it doubled in 2013, but after that, it kept on decreasing. The same trend has been observed in terrorist activities. The number of terrorists in Pakistan in 2012 was 676 in 2012 but increased to 735 in 2013. And just like poverty, the level of terrorists kept on falling after that. This postulates a direct relationship between poverty and terrorism.

Figure 1: Relationship between Poverty and Terrorism

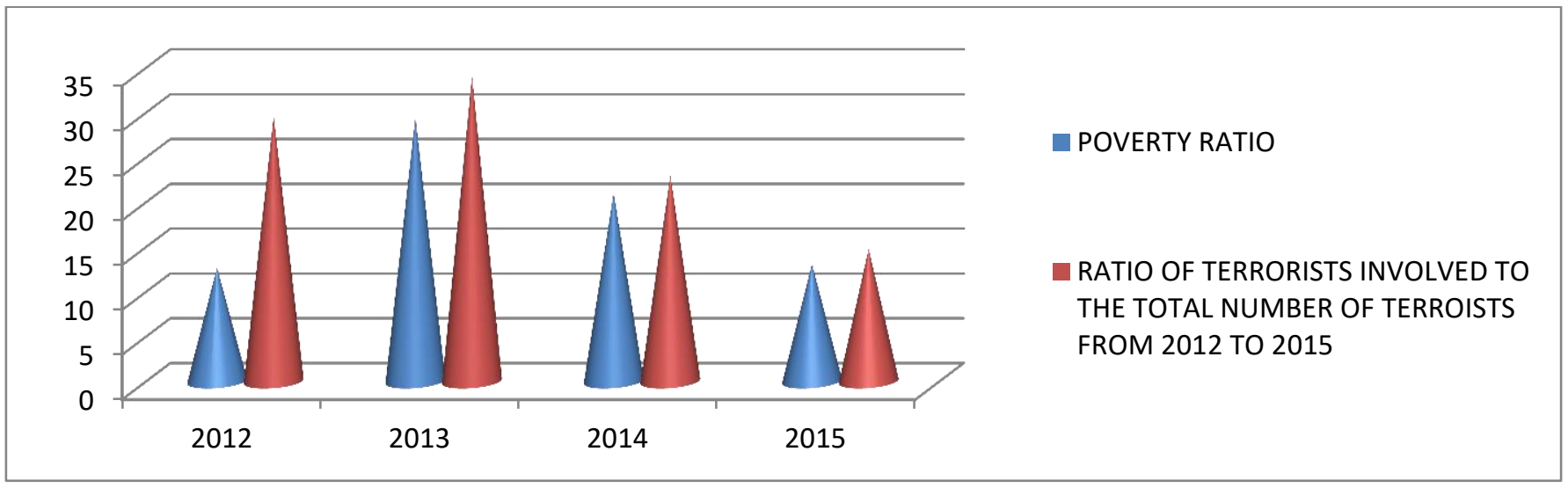

This figure shows that as the poverty ratio increased so did the level of terrorism and extremism in the country. From this analysis, it can be somewhat said that terrorism and extremism are economic problems.

Regional disparity means uneven, unbalanced, and unstable spatial structures in some regions or different regions. Regional disparities are demonstrated in different conditions of life as well as in unequal economic and progress potential. The contrast between city and rural areas can be also understood as a form of spatial disparity. Regional disparity is an economic problem because it is the 
difference in the development of different regions that leads to the different distribution of wealth. It is the regional differences that result in differences in per capita income and living standards of the people. It is a regional disparity that creates a sense of deprivation amongst the poor.

- The regions in Pakistan are:

- Baluchistan.

- Khyber Pakhtunkhwa.

- Punjab.

- Sindh.

- Islamabad- The Capital.

- FATA (Federally Administered Tribal Areas)

- Azad Kashmir.

- Gilgit-Baltistan.

Regional disparities result when either fewer funds are allocated to one region in comparison to the others or the budget of various provinces fails to finance the development projects in the regions. The statistics below show the value of the budget of the various provinces in different financial years.

Table 4: Budget of the Various Provinces in Different Financial Years

\begin{tabular}{|c|c|c|c|}
\hline & $\begin{array}{c}\mathbf{2 0 1 2 - 1 3} \\
\text { (PKR } \text { in billions) }\end{array}$ & $\begin{array}{c}\mathbf{2 0 1 3 - 1 4} \\
\text { (PKR in billions) }\end{array}$ & $\begin{array}{c}\mathbf{2 0 1 4 - 1 5} \\
\text { (PKR } \text { in billions) }\end{array}$ \\
\hline KPKP & 303.00 & 344.00 & 404.80 \\
\hline PUNJAB & 780.00 & 897.00 & 1349.40 \\
\hline SINDH & 577.00 & 617.00 & 739.00 \\
\hline BALOCHISTAN & 172.00 & 198.00 & 215.00 \\
\hline
\end{tabular}

It is evident that throughout the years Baluchistan has been the most deprived of all provinces and is the least developed. This type of depreciation creates hatred among the people and urges them to stand against the Government. The number of terrorists in Baluchistan and FATA has been increasing dramatically, and so are the terrorist activities in these regions. The figure below supports this fact

\section{Figure: Major Blasts in Pakistan (2012-2014)}

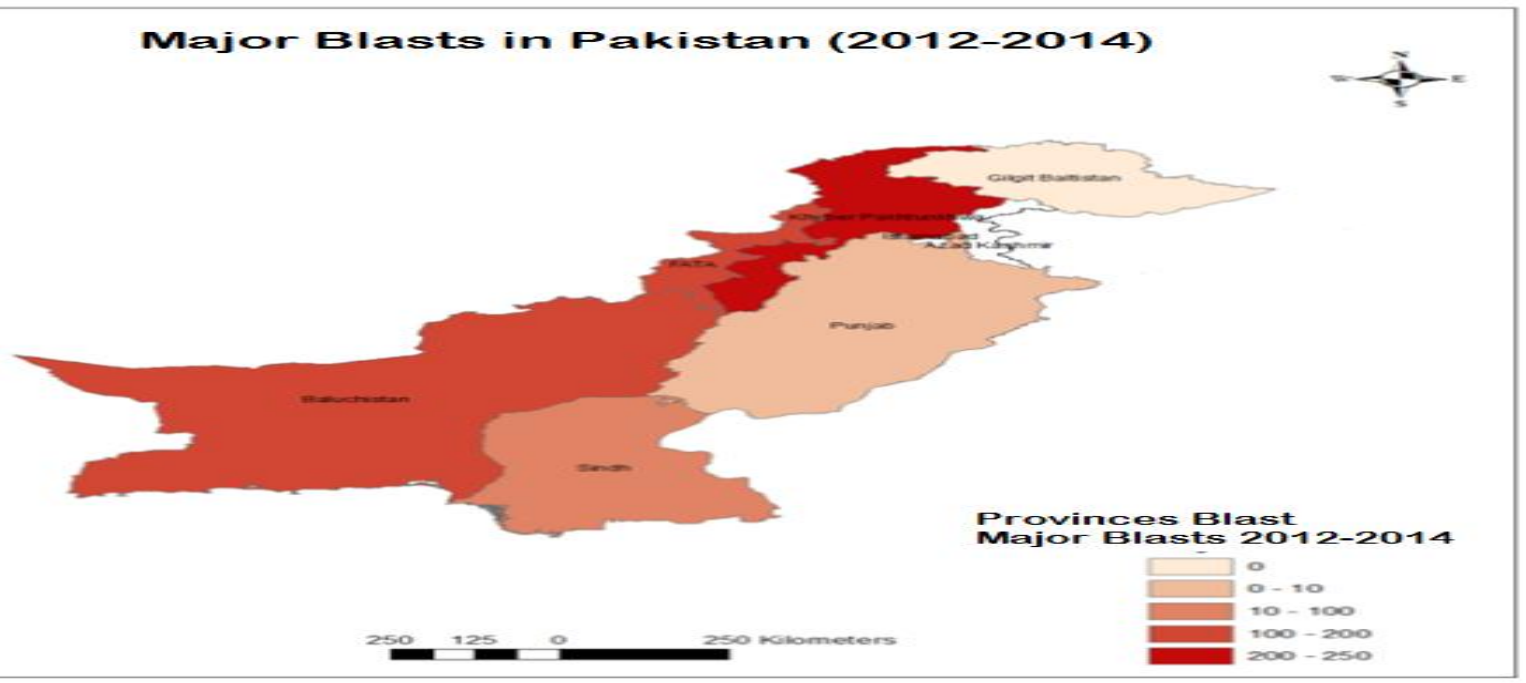


It clearly shows that the least developed province has been the victim of the most terrorist activities. This spatial analysis of war data in Pakistan from 2012 to 2014 supports the argument that regional disparities, imbalanced budget distribution and unequal allocation of funds damage the least developed province the most. From here it can be firmly concluded that Regional disparities are one of the major economic problems that result in the proliferation of terrorism and extremism.

\section{Conclusion}

From the above analysis, it has been found that "TERRORISM AND EXTREMISM ARE THE ECONOMIC problems AND NOT A POLITICAL ONE" The relationship between poor economic conditions and terrorism is very simple. One of the most important economic indicators is Poverty i.e. the number of people deprived of basic needs. When people don't get the necessities of their lives, they get frustrated. When people who want to earn a living, are unable to find a perfect job, they get angry. When people see politicians living a luxurious life using their taxes, they get disappointed. When people have to see their children crying out of hunger, they get exasperated.

It is this anger, frustration, disappointment, and exasperation that urges people to take the matter into their own hands. They lose their ability to distinguish between right and wrong. They get easily provoked against the government. This is the time when they get engaged in terrorist activities to show their anger. This is the time when they start killing people just to take out their frustration. This is the time when they don't even care about their own lives. This is the time when a terrorist is born every day. All they want is revenge. All they want is to disturb the life of the politicians who have made their lives miserable. To take revenge from the system, the terrorists kill the innocents. So, it can be rightly said that it is poverty that causes terrorism. It is unemployment that gives birth to extremists. It is a regional disparity that creates this much hatred among the people that they don't value each other lives. Overall, it's the poor economy that has led to the proliferation of terrorism and extremism.

\section{Recommendations}

In Pakistan, more than 50\% of people are living below the poverty line. This downtrodden section gets easily brainwashed. When they will not have food to eat and shelter to live and cloth to wear then for sure, terrorists can make them a target. The acts of viciousness and terrorism pose a risk to the government that pursues power by upsetting a weak public order and control. The economic condition of the country can only be improved if evils like corruption, bribery, and fraud are eliminated from society. It is because of these evils that the people who struggle hard day and night fail to get jobs. Unemployed people are unable to fulfill the necessities of their lives. This sense of deprivation, lack of job opportunities and low living standards all add to poverty.

If the problem of poverty and regional disparities is properly addressed by creating employment opportunities and adequate allocation of funds among the provinces through financial budget then the problem of terrorism and extremism can be solved to a large extent.

\section{References}

Aftab, S. (2008). Poverty and Militancy: Pakistan Institute for Peace Study, Knowledge for peace, p.01. Alan, B. K. (2004). Does Poverty Cause Terrorism. The New Republic.

Alberto, A. (2003). Poverty, Political Freedom, and the Roots of Terrorism. (NBER Working Paper No. 10859)

Azam, M. (2009). Radicalization in Pakistan: Socio-cultural Realities. PIPS Research Journal Conflict and 
Peace Studies. Islamabad.

Berrebi, C. (2007). Evidence about the link between education, poverty \& terrorism among Palestinians. Peace economics, peace science, and public policy: Vol. 13: Issue no. 1.

Burki, S. J. (2002). Terrorism and Development. The Dawn, May 21, 2002.

Campana, A. \& Lapointe, L. (2012). The Structural "Root" Causes of Non-Terrorism and Political Violence Vol. 24, 79-104.

Haqqani, H. (2005). The Ideologies of South Asian Jihadi Groups, Current Trends in Islamist Ideology, pp.12-26.

Krueger, A.B., Malenkov, J. (2003) Education, poverty \& terrorism: Is there a causal connection? Journal of Economic Perspectives.

Testas, A. (2004). Determinants of Terrorism in The Muslim World. Terrorism and Political Violence Vol.16, No.2, 253-273. 